\title{
Evaluation of mandarin hybrids grafted on 'Rangpur' lime in the Coastal Tablelands, Brazil
}

\author{
Lucas de Oliveira Ribeiro ${ }^{1}$, Eduardo Augusto Girardi ${ }^{2}$, Hélio Wilson Lemos de Carvalho ${ }^{3}$, \\ Debora Costa Bastos ${ }^{4}$, Walter dos Santos Soares Filho ${ }^{5}$, Orlando Sampaio Passos ${ }^{6}$
}

\begin{abstract}
The production of mandarins is incipient in Northeastern Brazil in spite of the large regional market. Few studies have reported the performance of mandarins under the tropical conditions in Brazil, considering that, in general, the quality and yield of these fruits are more expressive in regions of subtropical and Mediterranean climates. In this work, tree size, fruit production and quality of four mandarin hybrids ('Piemonte' mandarin-tangor, 'Murcott' tangor and 'Page' and 'Nova' tangelo-mandarin) grafted on 'Rangpur' lime rootstock in Umbaúba, State of Sergipe, Brazil, were evaluated. The experimental design was randomized blocks with three replicates and three trees per plot. Planting was carried out in 2008 at tree spacing of $6.0 \times 3.0 \mathrm{~m}$ in rainfed cultivation system. 'Piemonte' mandarin-tangor was more productive than 'Murcott' tangor and 'Nova' and 'Page' tangelo-mandarin, under the conditions evaluated in Umbaúba up to the eleventh year after planting. Regarding fruit quality, 'Piemonte' mandarin-tangor and 'Page' tangelo-mandarin can be indicated both for fresh consumption and for processing due to their higher total soluble solids, ratio and vitamin $\mathrm{C}$ content in relation to 'Murcott' tangor.
\end{abstract}

Index terms: Citrus spp., diversification of varieties, performance, fruit yield and quality.

\section{Avaliação de híbridos de tangerineira enxertados em limoeiro 'Cravo' para os Tabuleiros Costeiros}

Corresponding author: lucasdeoliveira2@yahoo.com.br

Received: January 27,2020 Accepted: August 14, 2020

Copyright: All the contents of this journal, except where otherwise noted, is licensed under a Creative Commons Attribution License.

\section{(cc) $\mathbf{E Y}$}

Resumo- A produção de tangerinas é incipiente na região Nordeste, embora o mercado consumidor regional seja expressivo. Há poucos estudos sobre o desempenho de tangerineiras nas condições tropicais do Brasil, considerando-se que, em geral, a qualidade e o rendimento de frutos dessas frutíferas sejam mais expressivos em regiões de clima subtropical e mediterrâneo. Neste trabalho, avaliaram-se crescimento de plantas, produção e qualidade de frutos de quatro híbridos de tangerineira (tangerineiratangor 'Piemonte', tangor 'Murcott' e tangerineira-tangelos 'Page' e 'Nova' ) enxertados em limoeiro 'Cravo', em Umbaúba-SE. O delineamento experimental foi em blocos casualizados, com três repetições e três plantas por parcela. O plantio foi realizado em 2008, no espaçamento de $6,0 \mathrm{~m}$ x 3,0 $\mathrm{m}$, em cultivo de sequeiro. A tangerineira-tangor 'Piemonte' foi mais produtiva que o tangor 'Murcott' e os tangerineira-tangelos 'Page' e 'Nova', nas condições avaliadas em Umbaúba-SE, até ao décimo primeiro ano de plantio. Para a qualidade dos frutos, a tangerineira-tangor 'Piemonte' e o Tangerineiratangelo 'Page' podem ser indicados tanto para o consumo in natura quanto para processamento, pois apresentaram resultados superiores para sólidos solúveis totais, ratio, rendimento industrial e vitamina C em relação ao tangor 'Murcott'.

Termos para indexação: Citrus spp., diversificação de variedades, desempenho, produção e qualidade de frutos. 


\section{Introduction}

Brazil is the world's fifth largest mandarin producer, and in 2018, produced 996,872 tons in cultivated area of 52,767 hectares (FAO, 2018). The state of São Paulo is the largest producer, with 384,714 tons in cultivated area of 10,819 hectares, followed by Minas Gerais, Paraná and Rio Grande do Sul, all of them with production above 100 thousand tons (IBGE, 2018). Brazilian tangerine production is mainly directed to the fresh domestic market (BASTIANEL et al., 2014). In São Paulo, 'Ponkan' mandarin (Citrus reticulata Blanco) and the 'Murcott' tangor [C. reticulata x C. $\times$ sinensis (L.) Osbeck)] share approximately $90 \%$ of the cultivated area (FUNDECITRUS, 2018).

In 2018, the Northeastern region of Brazil produced only 28,304 tons of mandarins (IBGE, 2018). Bahia and Sergipe stand out in the production of oranges, but the cultivation of mandarins is very small. In 2018, the production of mandarin in Bahia was 8,755 tons in cultivated area of 1,007 ha, while in Sergipe, 3,356 tons were produced in 480 ha. Paraíba has the largest mandarin production in the region, 13,257 tons in a cultivated area of 1,845 ha (IBGE, 2018). In all these states, orchards are concentrated in the Coastal Tablelands, a region with low rainfall and cohesive soils with low water retention (SOUZA et al., 2008). On the other hand, the regional consumer market is expressive, requiring research on varieties that suit the growing environment in this region and, thus, contribute to the diversification of crops and increase producers' income (ALMEIDA; PASSOS, 2011).

Climate is an important factor that influences the characteristics of mandarins, and fruits get larger with the increase in air temperature and relative air humidity. In tropical regions, with high and constant average temperature during seasons and with little thermal variation throughout the day, low fruit quality is usually observed due to the high respiratory activity of fruits, resulting in lower concentration of soluble solids and acidity (LADANIYA, 2008). The balanced relationship between these two juice attributes is decisive for the characteristic flavor of citrus (LIU et al., 2012). On the other hand, in regions with Mediterranean climate, with hot and dry summer, but mild humid winter and high thermal amplitude, fruits have high quality and, thus, greater commercial acceptance (LADANIYA, 2008). Climate also affects fruit peel, and the intensity of its color is regulated by the air temperature and the daily thermal amplitude: below $13{ }^{\circ} \mathrm{C}$, chlorophyll degradation and the accumulation of carotenoids are favored, while above 20 ${ }^{\circ} \mathrm{C}$ and with small amplitude, these processes are delayed (ALQUEZAR et al., 2008; LADO et al., 2018). Mandarins produced under temperatures above $30{ }^{\circ} \mathrm{C}$ have low quality (LAFUENTE et al., 2017).
To overcome this limitation and improve fruit quality, strategies such as crosses between species have become frequent in breeding programs, such as the crossing of mandarin trees such as 'Clementina' with grapefruit trees ( $C$. $\times$ paradisi Macfad.) originating hybrids called tangelos, which are commonly more adapted to tropical climates (DONADIO et al., 1998). In view of this scenario, the aim of the work was to evaluate plant growth, production and fruit quality variables of four mandarin hybrids ('Piemonte' mandarin-tangor, 'Murcott' tangor and 'Page' and 'Nova' tangelo-mandarin) grafted on 'Rangpur' lime in the Coastal Tablelands region within the scope of the diversification of scion cultivars to develop the citrus cultivation in this region.

\section{Material and methods}

The experiment was carried out in the municipality of Umbaúba, southern state of Sergipe (latitude: $11^{\circ} 23^{\prime} 00^{\prime \prime}$ S, longitude: $37^{\circ} 39^{\prime} 28^{\prime \prime} \mathrm{W}$, and $130 \mathrm{~m}$ a.s.1.). Planting was carried out in 2008, using 'Rangpur' lime (C. ×limonia Osbeck) as rootstock, as it is the most used in the region because it is highly drought-tolerant (ALMEIDA; PASSOS, 2011). Scion varieties used were four mandarin hybrids: 'Piemonte' mandarin-tangor $(C$. $\times$ clementina hort. ex Tanaka $\times$ 'Murcott' tangor), 'Murcott' tangor [probable $C$. reticulata Blanco $\times C$. $\times$ sinensis $(\mathrm{L}$.) Osbeck hybrid] and 'Page' tangelo [C. $\times$ clementina $\times$ 'Minneola' tangelo $(C . \times$ tangerina Tanaka 'Dancy' $\times C$. $\times$ paradisi Macfad. 'Duncan')] and 'Nova' tangelo [C. $\times$ clementina $\times$ 'Orlando' tangelo $(C . \times$ tangerina 'Dancy' $\times C . \times$ paradisi 'Duncan')]. The experimental design was randomized blocks, with three replicates and three plants per plot.

The climate in the experiment location is As type, hot and humid, according to the Köppen classification (tropical climate with rains in winter and dry summer), with average annual rainfall of $1,200 \mathrm{~mm}$ and average annual temperature of $24{ }^{\circ} \mathrm{C}$ (Figure 1). The soil is an Yellow Argisol, with medium texture, typical of the Coastal Tablelands, with cohesive layer of $20 \mathrm{~cm}$ to 60 $\mathrm{cm}$ in depth. In 2018, soil analysis was carried out on the planting line, verifying homogeneity of the area with the following averages in the $0-20 \mathrm{~cm}$ layer: $\mathrm{pH}$ (6.72); $\mathrm{P}$ (13.5 mg dm $\left.{ }^{-3}\right) ; \mathrm{K}\left(0.23 \mathrm{cmol}_{\mathrm{c}} \mathrm{dm}^{-3}\right) ; \mathrm{Ca}\left(2.22 \mathrm{cmol}_{\mathrm{c}} \mathrm{dm}^{-}\right.$ $\left.{ }^{3}\right) ; \mathrm{Mg}\left(0.86 \mathrm{cmol}_{\mathrm{c}} \mathrm{dm}^{-3}\right) ; \mathrm{Al}\left(0 \mathrm{cmol}_{\mathrm{c}} \mathrm{dm}^{-3}\right) ; \mathrm{Na}(0.012$ cmol $\left.\mathrm{dm}^{-3}\right)$; and O. M. $\left(21.2 \mathrm{~g} \mathrm{~kg}^{-1}\right)$; and $20-40 \mathrm{~cm}: \mathrm{pH}$ (6.27); P (3.75 mg dm $\left.{ }^{-3}\right) ; \mathrm{K}\left(0.18 \mathrm{cmol}_{\mathrm{c}} \mathrm{dm}^{-3}\right) ; \mathrm{Ca}(2.18$ $\left.\mathrm{cmol}_{\mathrm{c}} \mathrm{dm}^{-3}\right) ; \mathrm{Mg}\left(0.74 \mathrm{cmol}_{\mathrm{c}} \mathrm{dm}^{-3}\right) ; \mathrm{Al}\left(0 \mathrm{cmol}_{\mathrm{c}} \mathrm{dm}-3\right) ; \mathrm{Na}$ $\left(0.012 \mathrm{cmol}_{\mathrm{c}} \mathrm{dm}^{-3}\right)$; and O. M. $\left(11.7 \mathrm{~g} \mathrm{~kg}^{-1}\right)$. 


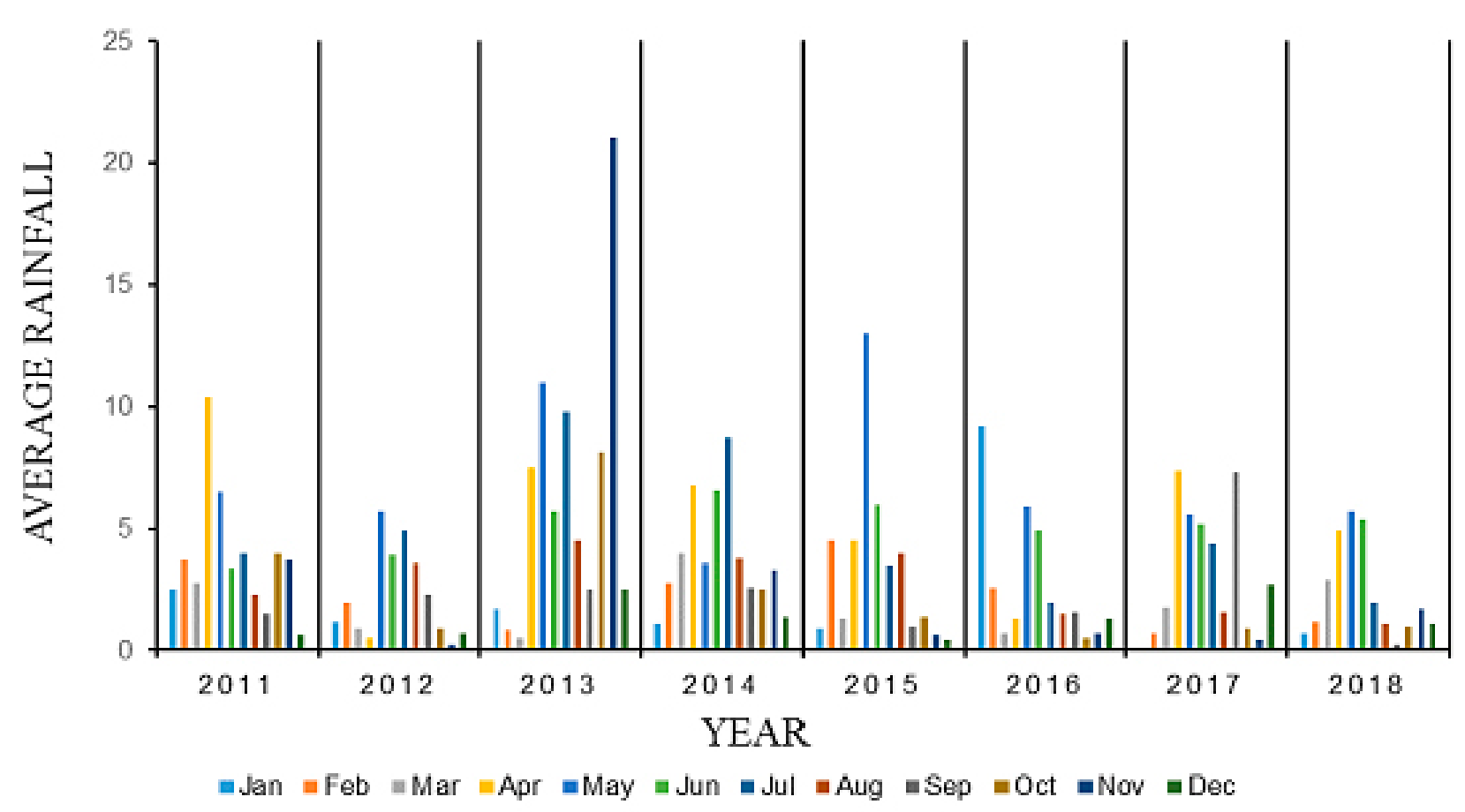

Figure 1. Monthly rainfall (mm) at the experiment location. Umbaúba, SE, 2011-2018.

The planting spacing was $6.0 \mathrm{~m} \times 3.0 \mathrm{~m}$ in rainfed system. Cultural practices used in the experimental area included mechanized mowing annually performed before harvesting, and harrowing was also carried out in the center of the line in 2017. There was no fruit pruning or thinning during the evaluation period. For the preventive control of the black fly, imidacloprid $(0.2 \mathrm{~mL}$ $\left.\mathrm{L}^{-1}\right)$ and buprofezin $\left(0.25 \mathrm{~mL} \mathrm{~L}^{-1}\right)$ were used, applied six times in 2017 and 2018, in a mixture with mineral oil or neutral detergent, without control measures in previous years due to insignificant incidence of pests in the area. For fertilization, $650 \mathrm{~g}$ of N-P-K [N (nitrogen), $\mathrm{P}_{2} \mathrm{O}_{5}$ (phosphorus pentoxide) and $\mathrm{K}_{2} \mathrm{O}$ (potassium oxide)] in the 20-10-20 formulation were applied always in the period of greatest rainfall occurrence. Complementary leaf fertilization with micronutrients was carried out twice a year, composed of boron $\left(5 \mathrm{~g} \mathrm{~L}^{-1}\right)$, manganese $\left(30 \mathrm{~g} \mathrm{~L}^{-1}\right)$, magnesium $\left(30 \mathrm{~g} \mathrm{~L}^{-1}\right)$, zinc $\left(40 \mathrm{~g} \mathrm{~L}^{-1}\right)$ and copper $\left(30 \mathrm{~g} \mathrm{~L}^{-1}\right)$. Cultivation conditions were representative of the reality of most citrus growers in the region.

From 2011 to 2016, shortly after the main crop was harvested, plant height (AP), from ground level to tree top (m), and canopy diameter (DC) were calculated by averaging the longitudinal and cross-section diameters $(\mathrm{m})$ in relation to the planting line, in the equatorial portion of the canopy, and then canopy volume $(\mathrm{VC})\left(\mathrm{m}^{3}\right)$ was calculated by $\mathrm{V}=2 / 3 \times\left[\left(\pi \times \mathrm{DC}^{2} \times 4^{-1}\right) \times \mathrm{AP}\right]$ (MOURÃO FILHO et al., 2007). From 2011 to 2018, the number of fruits per plant $(\mathrm{NF})$ and fruit production $(\mathrm{PF})\left(\mathrm{kg} \mathrm{plant}^{-1}\right)$ were evaluated, adding the harvests carried out each year, and the average fruit mass was calculated (MF) by the PF / NF ratio (g). The average production efficiency in 20142016 (EP) was calculated by dividing the production and the canopy volume in each year $\left(\mathrm{kg} \mathrm{m}^{-3}\right)$. Fruit yield (RF) by area $\left(\mathrm{kg} \mathrm{ha}^{-1}\right)$ was estimated in each year, in addition to the accumulated production (PA) in the evaluation period, adding annual yields. Alternate bearing index (IAP) was calculated for the period from 2011 to 2018, using the formula: IAP $=1 /(\mathrm{n}-1) \times\{|(\mathrm{a} 2-\mathrm{a} 1)| /(\mathrm{a} 2+\mathrm{a} 1)+\mid(\mathrm{a} 3-$ a2) $|/(\mathrm{a} 3+\mathrm{a} 2)+\ldots+|(\mathrm{a}(\mathrm{n})-\mathrm{a}(\mathrm{n}-1)) \mid /(\mathrm{a}(\mathrm{n})+\mathrm{a}(\mathrm{n}-1))\}$, where $n$ is the number of years and a1, a2, .., a (n-1), a (n) correspond to the production of the evaluated years (PEARCE;DOBERSEK-URBANC, 1967).

For fruit quality, the following variables were assessed: length (CF) and equatorial diameter of fruits (DF) $(\mathrm{cm})$, peel thickness (ESP) $(\mathrm{mm})$, juice percentage (SC) $(\%)$, titratable acidity (AT) $\left(\mathrm{g}\right.$ citric acid $\left.\mathrm{mL}^{-1}\right)$, concentration of soluble solids (SS) ( ${ }^{\circ}$ Brix) measured by refractometer; vitamin $\mathrm{C}(\mathrm{mg} / 100 \mathrm{~mL})$, industrial yield (RI) (estimation of the number of 40.8-kg boxes of mandarins to produce one ton of concentrated juice) and maturity ratio or index (SS/AT), according to methodology from the IAL (2008). Two to three harvests were carried out per year, the main harvest being usually in December due to higher fruit production. To carry out analyses, 10 uniform fruits were collected per plot in the main harvest of years 2014 and 2015, according to the visual assessment of their ripeness (skin color and fruit firmness). Fruit quality results were presented in terms of average values for 2014 and 2015 and for the two years separately in the case of variable SS. 
Results were submitted to analysis of variance and the means were compared by the Tukey test at 5\% probability, previously carrying out the square root transformation $(x+0.5)$ of variables plant height, number of fruits, fruit production per plant, production efficiency and fruit mass to meet data normality (FERREIRA, 1999).

\section{Results and discussion}

Mandarin hybrids showed significant differences in most variables evaluated, with coefficients of variation (CV) less than 20\% (Tables 1 to 4 ). This CV range is reported for studies of variety selection in citrus breeding using similar biometric variables (PIO et al., 2006; MOURÃO FILHO et al., 2007; BASSAL, 2009; BASTIANEL et al., 2014).
At nine years of age, mandarin canopies showed no statistical difference for plant height, canopy volume and productive efficiency, with averages of $3.10 \mathrm{~m}$, $18.71 \mathrm{~m}^{3}$ and $4.84 \mathrm{~kg} \mathrm{~m}^{-3}$, respectively (Table 1). In the entire experiment, no plant mortality was observed until 2018. 'Murcott' tangor and 'Piemonte' mandarin-tangor produced more fruits than 'Page' tangelo-mandarin, which in turn was superior to 'Nova' ttangelo-mandarin. 'Piemonte' mandarin-tangor produced heavier fruits than the other hybrids, and also had the highest average production among evaluated hybrids, $54.28 \mathrm{~kg}$ plant $^{-1}$, while 'Murcott' tangor, one of the most cultivated mandarin trees in Brazil, obtained $41.95 \mathrm{~kg}$ plant $^{-1}$ (Table 1).

Table 1. Plant height (AP), canopy volume (VC), production efficiency (EP), number of fruits per plant (NF), fruit weight (MF) and average fruit production per plant (PF) of mandarin hybrids grafted on 'Rangpur' lime in Umbaúba-SE.

\begin{tabular}{lcccccc}
\hline Mandarin hybrid & $\begin{array}{c}\mathrm{AP} * \\
(\mathrm{~m})\end{array}$ & $\begin{array}{c}\mathrm{VC}^{*} \\
\left(\mathrm{~m}^{3}\right)\end{array}$ & $\begin{array}{c}\mathrm{EP} * * \\
\left(\mathrm{~kg} \mathrm{~m}^{-3}\right)\end{array}$ & $\begin{array}{c}\mathrm{NF}^{* * *} \\
(\text { unit })\end{array}$ & $\begin{array}{c}\mathrm{MF}^{* * *} \\
(\mathrm{~g})\end{array}$ & $\begin{array}{c}\mathrm{PF}^{* * *} \\
\left(\mathrm{~kg} \mathrm{plant}^{-1}\right)\end{array}$ \\
\hline 'Nova' tangelo-mandarin & $2.58 \mathrm{a}$ & $13.42 \mathrm{a}$ & $6.12 \mathrm{a}$ & $202 \mathrm{c}$ & $168.36 \mathrm{~b}$ & $33.44 \mathrm{~b}$ \\
'Page' tangelo-mandarin & $3.43 \mathrm{a}$ & $21.81 \mathrm{a}$ & $3.64 \mathrm{a}$ & $251 \mathrm{~b}$ & $144.51 \mathrm{~b}$ & $34.80 \mathrm{~b}$ \\
'Piemonte' mandarin-tangor & $3.10 \mathrm{a}$ & $17.21 \mathrm{a}$ & $5.27 \mathrm{a}$ & $264 \mathrm{a}$ & $206.93 \mathrm{a}$ & $54.28 \mathrm{a}$ \\
'Murcott' tangor & $3.30 \mathrm{a}$ & $22.40 \mathrm{a}$ & $4.41 \mathrm{a}$ & $297 \mathrm{a}$ & $143.82 \mathrm{~b}$ & $41.95 \mathrm{~b}$ \\
\hline Mean & 3.10 & 18.71 & 4.84 & 254 & 165.90 & 41.12 \\
p-value & 0.017 & 0.243 & 0.140 & 0.001 & 0.002 & 0.011 \\
CV\% & 13.69 & 28.95 & 23.35 & 5.76 & 7.70 & 16.50 \\
\hline
\end{tabular}

* Average data for $2016 *$ ** Average data from 2014 to 2016; *** Average data from 2011 to 2018. Averages followed by the same letter do not differ by the Tukey's test at $5 \%$ probability.

Table 2 shows the annual production and accumulated production in the period from 2011 to 2018. Significant difference was observed in almost all years, with the exception of 2014 and 2016. From the year 2016, a decrease in the average production was observed, which probably occurred due to the occurrence of severe drought in the region (Figure 1). As planting was rainfed, the low water availability negatively affected the mandarins production, even using 'Rangpur' lime rootstock, reducing production until 2018.

Table 2. Annual fruit yield (RF), accumulated production (PA) and alternate bearing index (IAP) of mandarin hybrids grafted on 'Rangpur' lime in Umbaúba-SE in the period from 2011 to 2018.

\begin{tabular}{|c|c|c|c|c|c|c|c|c|c|c|}
\hline \multirow{2}{*}{ Mandarin hybrid } & \multicolumn{8}{|c|}{ Yield $\left(\mathrm{kg} \mathrm{ha}^{-1}\right)$} & \multirow{2}{*}{$\begin{array}{c}\mathrm{PA} \\
\left(\mathrm{kg} \mathrm{ha}^{-1}\right)\end{array}$} & \multirow{2}{*}{ IAP } \\
\hline & 2011 & 2012 & 2013 & 2014 & 2015 & 2016 & 2017 & 2018 & & \\
\hline 'Nova' tangelo-mandarin & $6325 b$ & $8494 b$ & $13002 b$ & $12934 \mathrm{a}$ & $27500 \mathrm{~b}$ & $15688 \mathrm{a}$ & $11999 b$ & $13038 b$ & $95943 c$ & $0.17 \mathrm{a}$ \\
\hline 'Page' tangelo-mandarin & $3674 \mathrm{c}$ & $13987 \mathrm{a}$ & $11975 b$ & $13805 \mathrm{a}$ & $19583 b$ & $21639 a$ & $10263 b$ & $13306 b$ & $94927 \mathrm{c}$ & $0.20 \mathrm{a}$ \\
\hline 'Piemonte' mandarin-tangor & $13564 a$ & $9427 b$ & $21711 \mathrm{a}$ & $15415 \mathrm{a}$ & $36018 \mathrm{a}$ & $23969 a$ & $17847 \mathrm{a}$ & $20557 \mathrm{a}$ & $137953 a$ & $0.22 \mathrm{a}$ \\
\hline 'Murcott' tangor & $14223 a$ & $4642 c$ & $12877 b$ & $12469 \mathrm{a}$ & $46018 \mathrm{a}$ & $17540 \mathrm{a}$ & $13903 a$ & $10774 \mathrm{~b}$ & $121674 b$ & $0.32 b$ \\
\hline Mean & 8874 & 8589 & 13900 & 12760 & 29951 & 18348 & 12619 & 13465 & 104116 & 0.23 \\
\hline $\mathrm{p}$-value & 0.000 & 0.000 & 0.000 & 0.043 & 0.000 & 0.314 & 0.000 & 0.000 & 0.000 & 0.008 \\
\hline CV\% & 10.05 & 16.28 & 13.69 & 8.47 & 10.62 & 30.20 & 13.48 & 11.78 & 6.56 & 16.38 \\
\hline
\end{tabular}

Averages followed by the same letter do not differ by the Tukey's test at $5 \%$ probability. 
In relation to the accumulated productivity, 'Piemonte' mandarin-tangor was the most productive, with production of $137,953 \mathrm{~kg} \mathrm{ha}^{-1}$. França et al. (2018), working with 'Piemonte' grafted on different rootstocks on the northern coast of Bahia, demonstrated the productive potential of this mandarin hybrid grafted on 'Sunki Tropical' [C. sunki (Hayata) hort. ex Tanaka] and 'Cleopatra' (C. reshni hort. ex Tanaka) mandarins, 'Riverside' citrandarin [C. sunki x Poncirus trifoliata (L.) Raf. 'English'-264] and 'Santa Cruz Rangpur' lime (C. $\times$ limonia). Carvalho et al. (2016) also demonstrated good production of 'Piemonte' mandarin-tangor in Sergipe on different rootstocks, such as 'Santa Cruz Rangpur' lime, 'Red' rough lemon (C. × jambhiri Lush.), 'Sunki Tropical' mandarin and 'Riverside' citrandarin. These results reinforce that 'Piemonte' mandarin-tangor is a hybrid with great potential to be introduced in commercial orchards in the Coastal Tablelands region, being an alternative to the standard variety, the 'Murcott' tangor.
According to Bassal (2009), alternate bearing index (IAP) ranges from 0 to 1 , with values $>0.5$ indicating production alternation, while values $<0.5$ suggest plants with regular harvests. 'Nova', 'Page' and 'Piemonte' were the least alternating hybrids, with IAP values of 0.17 , 0.20 and 0.22 , respectively, while 'Murcott' showed the highest alternation, 0.32 (Table 2). Several clementines and their hybrids have relatively low alternation rate among mandarin species (SILVA et al., 2018), as observed in this study.

Regarding fruit quality, only variable acidity was not significant among the evaluated hybrids, obtaining average of $0.65 \%$ (Table 3 ). The largest fruit diameters were observed for 'Piemonte' and 'Nova' hybrids, while 'Page' showed the smallest fruits. For fruit length, it was observed that 'Piemonte', 'Page' and 'Nova' hybrids obtained longer fruits compared to 'Murcott' (Table 3). In general, tangor fruits, notably 'Murcott', are flatter than most tangelos (SILVA et al., 2009). According to Ceagesp (2011), the studied hybrids meet the standards established by the Brazilian horticulture modernization program for mandarin fruit diameter, being qualified as medium in size (70 to $82 \mathrm{~mm}$ ), except for the 'Page' hybrid.

Table 3. Fruit diameter (DF), fruit length (CF), peel thickness (ESP), titratable acidity (AT), juice percentage (SC), vitamin C concentration (Vit C) and industrial yield (RI) of four mandarin hybrids grafted on 'Rangpur' lime in Umbaúba-SE in the period from 2014 to 2015 (average data).

\begin{tabular}{|c|c|c|c|c|c|c|c|}
\hline Mandarin hybrid & $\begin{array}{l}\mathrm{DF} \\
(\mathrm{cm})\end{array}$ & $\begin{array}{l}\mathrm{CF} \\
(\mathrm{cm})\end{array}$ & $\begin{array}{c}\mathrm{ESP} \\
(\mathrm{mm})\end{array}$ & $\begin{array}{l}\mathrm{AT} \\
(\%)\end{array}$ & $\begin{array}{l}\mathrm{SC} \\
(\%)\end{array}$ & $\begin{array}{c}\text { Vit C } \\
\left(\mathrm{mg} 100 \mathrm{~mL}^{-1}\right)\end{array}$ & $\begin{array}{c}\mathrm{RI} \\
\left(\mathrm{Cx} \mathrm{t}^{-1}\right)\end{array}$ \\
\hline 'Nova' tangelo-mandarin & $79.2 \mathrm{a}$ & $70.0 \mathrm{a}$ & $3.24 \mathrm{a}$ & $0.65 \mathrm{a}$ & $46.8 b$ & $45.9 \mathrm{a}$ & $357 b$ \\
\hline 'Page' tangelo-mandarin & $65.5 \mathrm{c}$ & $63.0 \mathrm{a}$ & $2.71 \mathrm{a}$ & $0.62 \mathrm{a}$ & $53.5 \mathrm{a}$ & $42.4 \mathrm{a}$ & $257 \mathrm{a}$ \\
\hline 'Piemonte' mandarin-tangor & $81.8 \mathrm{a}$ & $68.5 \mathrm{a}$ & $2.00 \mathrm{~b}$ & $0.68 \mathrm{a}$ & $54.2 \mathrm{a}$ & $42.8 \mathrm{a}$ & $279 \mathrm{a}$ \\
\hline 'Murcott' tangor & $73.2 b$ & $59.3 b$ & $1.80 \mathrm{~b}$ & $0.67 \mathrm{a}$ & $50.8 \mathrm{a}$ & $23.5 b$ & $349 b$ \\
\hline Mean & 74.9 & 65.2 & 2.44 & 0.65 & 51.3 & 38.7 & 311 \\
\hline p-value & 0.000 & 0.001 & 0.000 & 0.757 & 0.007 & 0.000 & 0.000 \\
\hline $\mathrm{CV} \%$ & 3.29 & 6.75 & 17.63 & 14.95 & 6.95 & 9.18 & 9.94 \\
\hline
\end{tabular}

Averages followed by the same letter do not differ by the Tukey's test at $5 \%$ probability. $\mathrm{Cx} \mathrm{t}^{-1}=$ number of 40.8 -kg boxes of tangerines to produce $1 \mathrm{t}$ of concentrated frozen juice.

Peel thickness is relevant for peeling, transporting and marketing purposes. It was found that 'Nova' and 'Page' tangelo-mandarin fruits had thicker peel that was more adhered to fruits, while 'Piemonte' mandarin-tangor and 'Murcott' tangor peel was thinner and less adhered to fruits, which facilitates peeling in relation to tangelos (Table 4). This characteristic is consistent with the origin of the evaluated hybrids, respectively crossings of mandarins with grapefruit (tangelos) and orange (tangors), with grapefruit peel being generally thicker than that of oranges.

For juice content, 'Piemonte', 'Murcott' and 'Page' had higher averages than 'Nova' hybrid (46.85\%), reflecting its greater peel thickness (Table 3). This behavior may also have occurred because 'Nova' tangelo-mandarin has tendency for fruit granulation as maturation increases, thus decreasing juice percentage (SAUNT, 1992). Borges and Pio (2003) observed similar results for 'Nova'tangelomandarin grafted on 'Rangpur' lime ( $45.2 \%$ juice) in Capão Bonito-SP. However, in Pelotas-RS, Malgarim et al. (2008) found a superior result for 'Nova' grafted on P. trifoliata $(58.75 \%)$, which probably stems from the milder and wetter climatic condition in southern Brazil, being more favorable to fruit development and quality of this hybrid in relation to warmer and drier regions, as in this study.

According to the Brazilian horticulture modernization program, juice percentage in mandarins must be at least 35\% (CEAGESP, 2011). In BorboremaPB, Silva et al. (2014), working with the 'Dancy' mandarin, the most cultivated variety in northeastern Brazil, obtained results similar to those found for the juice yield of hybrids 
evaluated in this study, two of which have the 'Dancy' variety in their genealogy. Thus, it was observed that the four hybrids have significant potential for increasing the amount of juice in mandarin fruits in the environmental conditions of northeastern Brazil.

Table 4. Concentration of soluble solids (SS) and maturation index or ratio (SS/AT) of four mandarin hybrids grafted on 'Rangpur' lime in Umbaúba-SE in 2014 and 2015.

\begin{tabular}{llllc}
\hline \multirow{2}{*}{ Mandarin hybrid } & \multicolumn{2}{c}{$\mathrm{SS}\left({ }^{\circ}\right.$ Brix $)$} & 2014 & 2015 \\
\hline 'Nova' tangelo-mandarin & 2014 & 2015 & $12.95 \mathrm{c}$ & $17.29 \mathrm{a}$ \\
'Page' tangelo-mandarin & $11.83 \mathrm{a}$ & $11.86 \mathrm{~b}$ & $17.69 \mathrm{a}$ & $20.20 \mathrm{a}$ \\
'Piemonte' mandarin-tangor & $10.53 \mathrm{~b}$ & $11.0 \mathrm{~b}$ & $14.53 \mathrm{~b}$ & $17.36 \mathrm{a}$ \\
'Murcott' tangor & $8.66 \mathrm{c}$ & $9.66 \mathrm{c}$ & $12.06 \mathrm{c}$ & $16.57 \mathrm{a}$ \\
\hline Mean & 10.1 & 10.63 & 14.31 & 17.86 \\
p-value & 0.000 & 0.028 & 0.021 & 0.121 \\
CV\% & 4.98 & 7.19 & 12.47 & 9.52 \\
\hline
\end{tabular}

Averages followed by the same letter do not differ by the Tukey's test at $5 \%$ probability.

Working with 'Murcott' tangor in Itirapina-SP, Figueiredo et al. (2006) showed superior results for juice yields, above $51 \%$, in addition to ratio greater than 17, when grafted on 'Rangpur' lime, 'Orlando' tangelo, 'Caipira DAC' orange (C. × sinensis), 'Kryder 8-5' and 'EEL' trifoliate orange ( $P$. trifoliata) and 'Satsuma' (C. unshiu Marcow.), 'Cleopatra', 'Sunki' (C. sunki), 'Batangas', 'Oneco', 'Swatow', 'Szinkon', 'Cravo', 'Suen Kat', 'Pook Ling Ming' (C. reticulata) and 'Dancy' mandarins. Under the conditions evaluated by these authors, the average annual rainfall was $1,600 \mathrm{~mm}$ and the average air temperature was $20^{\circ} \mathrm{C}$, conditions that are quite different from those observed in Sergipe (Figure 1), which may explain, in part, the quality differences found for this hybrid.

Regarding industrial yield (RI), it was observed that the smaller the number of boxes used to make one ton of juice, the better the variety performance. The best yields were obtained for 'Page' tangelo mandarin tree, with 257 boxes $\mathrm{t}^{-1}$, and 'Piemonte' mandarin-tangor, with 279 boxes $\mathrm{t}^{-1}$, suggesting that both have differentiated potential for juice processing, reinforced by their higher soluble solids concentration, in which 'Page' tangelo mandarin tree obtained $11.83{ }^{\circ}$ Brix and $11.86^{\circ}$ Brix in years 2014 and 2015, respectively, above 'Piemonte' mandarin-tangor, which presented $10.53{ }^{\circ}$ Brix in 2014 and $11.0{ }^{\circ}$ Brix in 2015. The lowest concentrations were obtained for 'Murcott' tangor, but 'Nova' tangelo mandarin tree was equivalent to 'Piemonte' mandarin-tangor (Table 4), and its RI was affected by the lower juice content (Table 3). However, all SS values are above those established for commercial mandarins, of at least $9{ }^{\circ}$ Brix (CEAGESP, 2011). This high SS may have been observed because the orchard was cultivated without irrigation, obtaining fruits with lower juice yield, which favors the accumulation of sugar, ratio and flavonoids (LADO et al., 2018; GRILO et al ., 2017). In California-USA, Furr et al. (2014) reported for 'Furr' mandarin, probably equivalent to 'Piemonte' (FRANÇA et al., 2018), soluble solids content of $13^{\circ}$ Brix when grafted on 'Carrizo' citrange ( $P$. trifoliata $\times C$. $\times$ sinensis), corroborating the high quality of this hybrid. Regarding the vitamin C concentration, 'Murcott' tangor showed only $23.54 \mathrm{mg} 100 \mathrm{~mL}^{-1}$, being about $50 \%$ lower than the concentration of the other hybrids. This lower value for 'Murcott' tangor may be related to its genetic origin $(C$. reticulata $\times C$. $\times$ sinensis $)$, different from the other mandarin hybrids that have 'Clementina' mandarin as parent, which in turn produces fruits rich in vitamin $\mathrm{C}$ (CANAN et al., 2016).

The ratio is the relationship between soluble solids and acidity and expresses the degree of ripeness of citrus fruits, being an indicator of flavor (LADO et al., 2018). In 2014, 'Page' tangelo mandarin tree had the highest ratio, 17.69 , above 'Piemonte' which in turn was earlier than the other two hybrids. In 2015, there was no difference, although the trend was similar. In Bahia, 'Piemonte' mandarin-tangor showed ratio value (FRANCE et al., 2018), higher than that of 'Dancy' mandarin (SILVA et al., 2014), suggesting that 'Piemonte' should be harvested outside the harvest peak of mandarins in northeastern Brazil, which is a very important factor for the marketing of fruits, as they will obtain better prices. All hybrids obtained ratio values above 12 , higher than those required for the marketing of mandarins, which is at least 9.5 (CEAGESP, 2011). According to Ramalho (2005), this attribute can range from 6 to 20 , with 15 to 18 being the range preferred by consumers. 
In the processing of mandarin juice, bitterness can occur due to the presence of flavonoids and limonoids (BREKSA III et. al., 2005; IGLESIAS et al., 2007). However, 'Murcott' tangor has important characteristics to minimize this factor in the processed juice, such as sweet taste and attractive color, being also indicated for industry (CHIARINI et al., 2017). In this study, 'Piemonte' mandarin-tangor and 'Page' and 'Nova' tangelo-mandarin presented several juice attributes similar or superior to those of 'Murcott' tangor, encouraging further studies on the potential of these hybrids for juice processing, notably pasteurized, as option for use in Brazil.

Although 'Murcott' tangor is one of the mandarins most cultivated in Brazil, with fruits intended for both fresh consumption and juice processing (CHIARINI et al., 2017), this work presented hybrids with superior production and/or quality traits under the Coastal Tablelands conditions. Thus, they are alternatives with great potential for commercial recommendation, providing wider range of citrus portfolio, and opportunity for more income for growers in the region. It is important to highlight that the four hybrids under study are susceptible to Alternaria alternata brown spot (PERES; TIMMER, 2006; REIS et al., 2006; FRANÇA et al., 2018), requiring adequate control of this disease, even if it is favored in wetter climate conditions (TIMMER et al., 2000).

\section{Conclusion}

'Piemonte' mandarin-tangor is more productive than 'Murcott' tangor and 'Nova' and 'Page' tangelomandarin under the conditions evaluated in Umbaúba-SE until the eleventh year of planting.

For fruit quality, 'Piemonte' mandarin-tangor and 'Page' tangelo-mandarin can be indicated both for fresh consumption and potentially for juice processing, as they obtained superior results for soluble solids, vitamin C, industrial yield and ratio in relation to 'Murcott' tangor in the Coastal Tablelands region.

\section{Acknowledgments}

To the Coordenação de Aperfeiçoamento de Pessoal de Nível Superior (CAPES), for the Doctorate scholarship of the first author - financing code 001; to Embrapa Mandioca e Fruticultura, for the supply of plant materials and financial support (Process 20.18.01.007.00.00); to the Experimental Station of Embrapa Tabuleiros Costeiros in Umbaúba-SE, for conducting the experiment; and to agricultural technician José Raimundo dos Santos, for technical support.

\section{Referências}

ALMEIDA, C.O.; PASSOS, O.P. Citricultura brasileira em busca de novos rumos: desafios e oportunidades na região Nordeste. Cruz das Almas: Embrapa Mandioca e Fruticultura; 2011. 160 p.

ALQUEZAR, B.; RODRIGO, M.J.; ZACARÍAS, L. Carotenoid biosynthesis and their regulation in citrus fruits. Tree and Forestry Science and Biotechnology, Madison, v.2, n.1, p.23-35, 2008.

BASSAL, M.A. Growth, yield and fruit quality of 'Marisol' clementine grown on four rootstocks in Egypt. Scientia Horticulturae, Amsterdam, v.119, n.2, p.132137, 2009.

BASTIANEL, M.; SIMONETTI, L.M.; SCHINOR, E.H.; GIORGI NETO, R.O.; DE NEGRI, J; D.; GOMES, D.N.; AZEVEDO, F.A. Avaliação do banco de germoplasma de mexericas com relação às características físico-químicas e suscetibilidade à mancha marrom de alternária. Bragantia, Campinas, v.73, p.23-31, 2014.

BORGES, R.S.; PIO, R.M. Comparative study of the mandarin hybrid fruit characteristics: nova, murcott and ortanique in Capão Bonito-SP, Brazil. Revista Brasileira de Fruticultura, Jaboticabal, v.25, n.3, p.448-452, 2003.

BREKSA III, A.P.; ZUKAS, A.A.; MANNERS, G.D. Determination of limonoate and nomilinoate A-ring lactones in citrus juices by liquid chromatographyelectrospray ionization mass spectrometry. Journal of Chromatography A, Amsterdam, v.1064, p.187-191, 2005.

CANAN, I.; GÜNDOĞDU, M.; SEDAY, U.; OLUK, C.A.; KARAȘAHIN, Z.; EROĞLU, E.C.; YAZICI, E.; ÜNLÜ, M. Determination of antioxidant, total phenolic, total carotenoid, lycopene, ascorbic acid, and sugar contents of Citrus species and mandarin hybrids. Turkish Journal of Agriculture and Forestry, Ankara, v.40, p.1-6, 2016.

CARVALHO, H.W.L.; MARTINS, C.R.; TEODORO, A.V.; SOARES FILHO, W.S.; PASSOS, O.S. Agronomical performance of 'Piemonte' mandarin grafted on several rootstocks in the Brazilian Coastal Tablelands. Pesquisa Agropecuária Brasileira, Brasilia, DF, v.51, n.11, p.1830$1838,2016$.

CEAGESP - Companhia de Entrepostos e Armazéns Gerais de São Paulo. Normas de classificação de citros de mesa. São Paulo, 2011. 12p. 
CHIARINI, R.F.; JACOMINO, A.P.; ARRUDAPALHARINI, M.C.; SILVA, A.P.G.; ANDRADE, C.A.W. Processamento mínimo de tangerina-tangor 'Murcott': tipos de corte, sanificação e eliminação do excesso de líquidos. Brazilian Journal Food Technology, Campinas, v.20, e.2016041, 2017.

DONADIO, L.C.; STUCHI, E.S.; CYRILLO, F.L.L. Tangerinas ou mandarinas. Jaboticabal: Funep, 1998. 40 p. (Boletim citrícola, 5).

FAO - Food and Agriculture Organization of the United Nations. Faostat 2018. Disponível em: http://faostat.fao. org/site/535/default.aspx\#ancor. Acesso em: 01 fev. 2020.

FERREIRA, D.F. Sisvar 4.3 - sistema de análises estatísticas. Lavras: Universidade Federal de Lavras, 1999.

FIGUEIREDO, J.O.; NEGRI, J.D.; MATTOS JUNIOR, D.; PIO, R.M.; F.A.A.; GARCIA, V.X.P.Comportamento de 16 porta-enxertos para o tangerina-tangor 'Murcott' na região de Itirapina-sp.Revista Brasileira de Fruticultura, Jaboticabal, v.28, n.1, p.76-78, 2006.

FRANÇA, N.O.; GIRARDI, E.A.; AMORIM, M.S.; GESTEIRA, A.S.; PASSOS, O.S.; SOARES FILHO, W.S. Plant growth, yield and fruit quality of 'Piemonte' tangerine-tangor grafted onto 14 rootstocks on the northern coast of the state of Bahia, Brazil. Revista Brasileira de Fruticultura, Jaboticabal, v.40, n.4, e-784, 2018.

FUNDECITRUS - Fundo de Defesa da Citricultura. Inventário de árvores e estimativa da safra de laranja do cinturão citrícola de São Paulo e triângulo/sudoeste mineiro 2017/2018: retrato dos pomares em março de 2018 . Araraquara, 2018. 95p.

FURR, J.; REECE, P.; KAHN, T.; SIEBERT, T.; BARRY, G.; MCCOLLUM, G.; CASTLE, W.; STOVER, E. 'US Furr' and 'US Furr-ST' Mandarins. Journal of the American Pomological Society, Pennsylvania, v.68, n.4, p.198-203, 2014.

GRILO, F.S.; DI STEFANO, V, LO BIANCO, R. Deficit irrigation and maturation stage influence quality and flavonoid composition of 'Valencia' orange fruit. Journal Science Food Agriculture, London, v.97, p.904-909, 2017.

IGLESIAS, D.J.; CERCÓS, M.; COLMENEROFLORES, J.M.; NARANJO, M.A.; RIOS, G.; CARRERA, E.; RIVERO, O.R.; LLISO, I.; MORILLON, R.; TADEO, F.R.; TALON, M. Physiology of citrus fruiting. Brazilian Journal Plant Physiology, Campos dos Goytacazes, v.19, n.4, p.333-362, 2007.
IAL - INSTITUTO ADOLFO LUTZ. Métodos físicoquímicos para análise de alimentos. São Paulo, 2008, $1020 \mathrm{p}$.

IBGE - Instituto Brasileiro de Geografia e Estatística. Levantamento sistemático da produção agrícola estatística da produção agrícola. Rio de Janeiro, 2018. $85 \mathrm{p}$.

LADANIYA, M.S. Citrus fruit, biology, technology and evaluation. London: Academic Press; 2008.

LADO, J.; GAMBETTA, G.; ZACARIAS, L. Key determinants of citrus fruit quality: Metabolites and main changes during maturation. Scientia Horticulture, Amsterdam, v.233, p.238-248, 2018.

LAFUENTE, M.T.; ESTABLÉS-ORTÍZ, E.; GONZÁLEZCANDELAS, L. Insights into the molecular events that regulate heat-induced chilling tolerance in citrus fruits. Frontiers in Plant Science, Lausanne, v.8, p.1113, 2017.

LIU, Y.; HEYING, E.; TANUMIHARDJO, S.A. History, global distribution, and nutritional importance of citrus fruits. Revista Food Science, Campinas, v.11, p.530-545, 2012.

MALGARIM, M.B.; FLORES CANTILLANO, R.F.; OLIVEIRA, R.P.; TREPTOW, R.O. Qualidade póscolheita de citros 'Nova' em diferentes períodos de armazenamento e comercialização. Revista Brasileira de Agrociência, Pelotas, v.14, n.1, p.19-23, 2008.

MOURÃO-FILHO, F.A.A.; ESPINOZA-NÚÑEZ, E.; STUCHI, E.S.; ORTEGA, E.M.M. Plant growth, yield, and fruit quality of 'Fallglo' and 'Sunburst' mandarins on four rootstocks. Scientia Horticulturae, Wageningen, v.114, n.1, p.45-49, 2007.

PEARCE, S.M.; DOBERSEK-URBANC, S. The measurement of irregularity in growth and cropping. Journal of Horticultural Science, Ashford, v.42, n.3, p.295-305, 1967.

PERES, N.A.; TIMMER, L.W. Evaluation of the alterrater model for spray timing for control of Alternaria brown spot on Murcott tangor in Brazil. Crop Protection, Amsterdam, v.25, n.5, p.454-460, 2006.

PIO, R.M.; DE AZEVEDO, F.A; DE NEGRI, J.D.; FIGUEIREDO, J.O.; CASTRO, J.L. Características da variedade 'Fremont' quando comparadas com as das tangerinas 'Ponkan' e 'Clementina Nules'. Revista Brasileira Fruticultura, Jaboticabal, v.28, n.2, p.222226, 2006. 
RAMALHO, A.S.T.M. Sistema funcional de controle de qualidade a ser utilizado como padrão na cadeia de comercialização de Laranja Pêra (Citrus sinensis L.Osbeck). 2005. 91f. Dissertação (Mestrado em Ciência e Tecnologia de Alimentos) - Escola Superior de Agricultura Luiz de Queiroz, Piracicaba, 2005.

REIS, R.F.; GOES, A.D.E.; MONDAL, S.M.; TIMMER, L.W. Effectiveness of fungicides and susceptibility of fruit and leaves of tangerine, tangor and tangelos to infection by Alternaria alternata, the cause of brown spot. Summa Phytopathologica, Botucatu, v.32, p.1-12, 2006.

SAUNT, J. Variedades de cítricos del mundo: guia ilustrada. Valência: Sinclair Internacional, 1992. 128p.

SILVA, A.P.G.; SILVA, S.M.; SCHUNEMANN, A.P.P.; DANTAS, A.L.; DANTAS, R.L.; SILVA, J.A.; MENDONÇA, R.M.N. Qualidade de tangerinas 'Dancy' produzidas no território da Borborema, estado da Paraíba. Revista Agropecuária Técnica, Paraíba, v.35, n.1, p.134142, 2014.
SILVA, S.R.; GIRARDI, E.A.; SANTOS, M.G.; CANTUARIAS-AVILÉS, T.E.; STUCHI, E.S. Plant growth, yield and fruit quality of Clementine mandarin selections under subtropical climate in Brazil. Revista Brasileira de Fruticultura, Jaboticabal, v.40, n.4, e.051, 2018.

SILVA, S.R.; OLIVEIRA, J.C.; STUCHI, E.S.; REIFF, E.T. Qualidade e maturação de tangerinas e seus híbridos em São Paulo. Revista Brasileira de Fruticultura, Jaboticabal, v.31, n.4, p.977-986, 2009.

SOUZA, L.S.; SOUZA, L.D.; PAIVA,A.Q.; RODRIGUES, A.C.V.; RIBEIRO, L.S. Distribuição do sistema radicular de citros em uma topossequência de solos de Tabuleiro Costeiro do Estado da Bahia. Revista Brasileira de Ciência do Solo, Viçosa, MG, v.32, n.2, p.503-513, 2008.

TIMMER, L.W.; SOLEL, Z.; OROZCO SANTOS, M. Alternaria brown spot of mandarin. In: TIMMERS, L.W.; GANSEY, S.M.; GRAHAM, J.H. (ed.). Compendium of citrus diseases. 2.ed. Minnesota: APS Press, 2000. p.19-20. 